\title{
Socializing space and politicizing financial innovation/destruction: some observations on Occupy Wall Street
}

Socialisation de l'espace et politisation de l'innovation/destruction financière: quelques réflexions sur le mouvement "Occupy Wall Street"

\section{Manuel B. Aalbers}

\section{OpenEdition}

\section{Journals}

Electronic version

URL: http://journals.openedition.org/belgeo/6155

DOI: $10.4000 /$ belgeo.6155

ISSN: 2294-9135

Publisher:

National Committee of Geography of Belgium, Société Royale Belge de Géographie

\section{Electronic reference}

Manuel B. Aalbers, «Socializing space and politicizing financial innovation/destruction: some observations on Occupy Wall Street », Belgeo [Online], 1-2 | 2012, Online since 15 December 2012, connection on 19 April 2019. URL : http://journals.openedition.org/belgeo/6155; DOI : 10.4000/ belgeo.6155

This text was automatically generated on 19 April 2019.

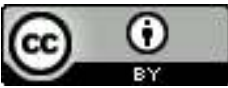

Belgeo est mis à disposition selon les termes de la licence Creative Commons Attribution 4.0 International. 


\title{
Socializing space and politicizing financial innovation/destruction: some observations on Occupy Wall Street
}

\author{
Socialisation de l'espace et politisation de l'innovation/destruction financière: \\ quelques réflexions sur le mouvement "Occupy Wall Street"
}

Manuel B. Aalbers

\section{Introduction}

1 Most protests call for specific changes in specific places. Higher wages, shorter work weeks, equal pay for men and woman, no more separated seating in buses, no more budget cuts, no more bombs, no more discrimination. Usually such demands are specific to a city or country or even to one economic sector within that city or country. In that light, the demands of Occupy Wall Street (OWS) and its offshoots around the globe are not clear. What is it that OWS wants, from whom and where? The easiest answer would be : less power to Wall Street investment banks. But the calls of OWS seem to be targeted as much at the Wall Street investment banks as at other financial institutions, as much at the financial sector as at the state, and as much as U.S. institutions as at non-U.S. institutions. One can easily argue that OWS does not have a clear agenda, but the same could easily be said about the politicians who muddle through the crisis. In this intervention, I will not attempt to answer these questions nor will I try to explain why it took four years into the crisis for OWS to emerge. Rather I will focus on two issues that both present OWS as something that is bigger than Wall Street. First, I will present a local urban political geography by focusing on the occupied pocket park. Second, I will present a global financial political geography by focusing on how the imprecise demands of OWS are a result not so much of the heterogeneous base of OWS but of the still largely unknown and "under-understood" nature of finance. 


\section{A Local Urban Political Geography}

OWS has not physically occupied Wall Street, it has occupied a pocket park formerly known as Liberty Plaza, but renamed to Zuccotti Park in 2006. The word plaza is, however, a better indication of the space : a small, mostly paved strip of land that has big granite blocks, a Mark di Suvero sculpture and a little bit of greenery. Yet, it is a small oasis in the maze of streets and high-rises that is Lower Manhattan. A well used public space, in particular during lunch hour, Zuccotti Park is two short blocks from the actual Wall Street, right between the World Trade Center Site/Ground Zero and the financial institutions of Wall Street and Broad Street. On the short sides two major thoroughfares bound the plaza : Broadway and Trinity Place/Church Street. The "park" is named after the U.S. chairman of Brookfield Properties, the company who paid for the design of the square and formally owns it but is required to maintain it as a public place. (Brookfield has its offices a few blocks away at World Financial center and also owns the building adjacent to Zuccotti Park, One Liberty Plaza, which accommodates offices of NASDAQ, Zurich American Insurance, Royal Bank of Canada, the Financial Industry Regulatory Authority and others.) OWS has therefore not only occupied a strategically located space close to the Wall Street investment banks, it has also occupied a privatized public space. The irony is that many of the occupiers, despite protesting against corporate capitalism are frequent visitors of nearby fast food chains, in particular the McDonald's only half a block away at Broadway, where they drink coffee, eat apple pie (many of them are vegetarians), use the bathrooms and charge their cell phones. This was not the first time that it struck me how global chains such as McDonald's, Starbucks and Ikea had become essential public meetings places, in part because in many places there are fewer and fewer alternatives. 
Figure 1. Liberty Plaza in the middle of the Financial District.

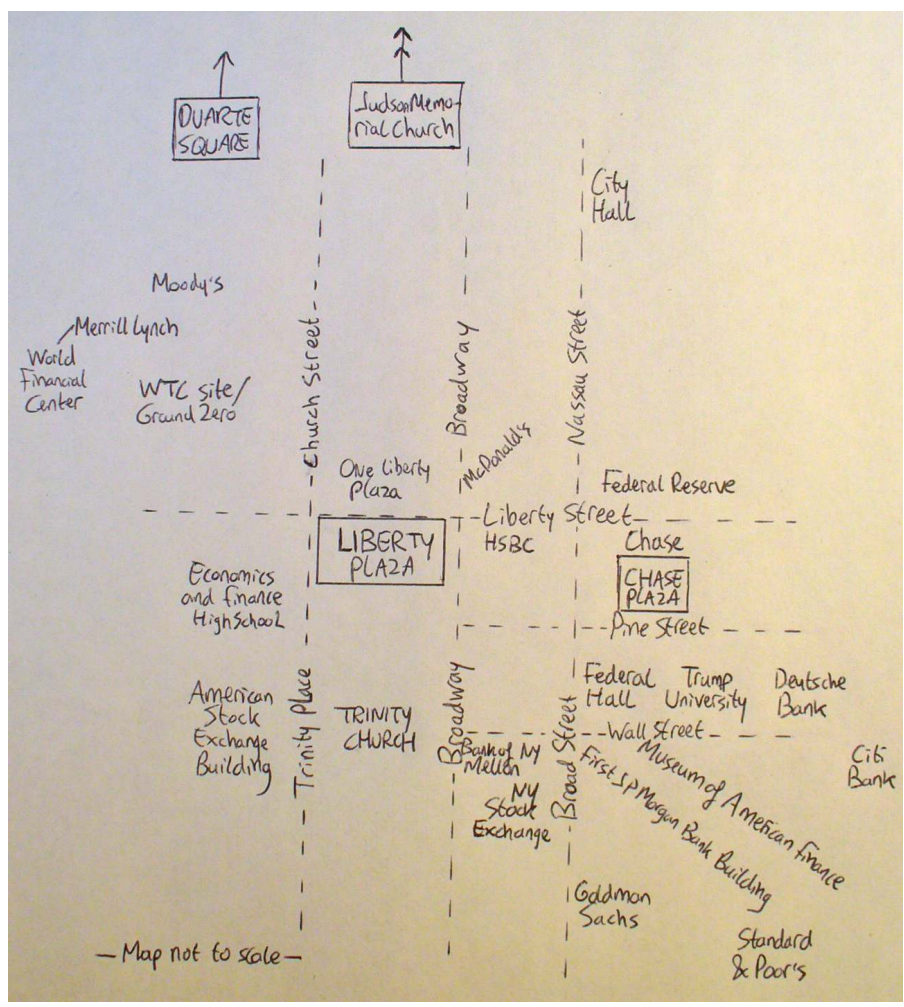

The original Liberty Plaza was built in the early 1970s under a section of the NYC zoning code known as a "privately owned public space" (POPS). The so-called "plaza bonus" is the most popular of the different zoning bonuses and it basically allows for the development of additional square feet of office space as a reward for creating a publicly accessible yet privately owned and managed public space. In this case the developer of the office building One Liberty Plaza was allowed to add more than 300,000 square feet or a full nine floors to his building. Since POPS was initiated in 1968, 526 plazas at 372 buildings have been built, mostly in Lower and in particular Midtown Manhattan. Some of these plazas are among the most treasured and intensively used spaces in the city while others are de facto shut off from the general public, either by design or by surveillance. Another irony is that the OWS movement originally planned to occupy the nearby plaza in front of Chase Bank, another POPS two blocks away, but private security didn't allow the protesters access to the plaza. Although OWS was primarily aimed at financial institutions and the federal government, it explicitly also wanted to use a POPS as a fundamental public space and thereby politicize the privatization of the public sphere. If the financial crisis was about privatizing profit and socializing risk, OWS is about politicizing state/market relations and socializing space. OWS targets both the financialization of the economy and the privatization of public space as well as the neoliberal logic and market fundamentalism that underlies both.

4 At times, Brookfield has requested the mayor and the New York Police Department (NYPD) to evict the demonstrators. The NYPD has not been in favor of eviction as it is easier to contain the occupiers in one easily surveillable place than have the protestors sprawl out around Lower Manhattan. Mayor Bloomberg at some point announced the eviction from the plaza, but both he and Brookfield have been pressed by local politicians to cancel any eviction plans as they did not support those and could backfire on both the 
mayor and Brookfield. For a few weeks the strategy of "Brookberg" or "Bloomfield" seemed to be to freeze the protesters out, but on the night of November 14-15, 2011 the Mayor had Liberty Plaza cleared without prior announcement. The Mayor's statement read : "The law that created Zuccotti Park required that it be open for the public to enjoy for passive recreation 24 hours a day. Ever since the occupation began, that law has not been complied with, making it unavailable to anyone else." That night about 200 people were arrested. After the plaza was cleaned, the protesters were allowed back in, but they were not allowed to put up tents or sleep on the plaza. Some protesters temporarily decamped to nearby squares, including Foley Square in the middle of the Civic Center and Duarte Square, a "space left over after planning" (SLOAP) partly owned by the City and partly by Trinity Church one of the biggest landowners in Downtown Manhattan. Again others camped out at Judson Memorial Church at Washington Square Park. Contrary to Trinity Church, Judson Memorial Church is a long-time supporter of community and social movements. In the weeks prior to the clearing of Liberty Plaza, occupy movements had not only spread throughout the U.S. and around the globe, but spin-offs were also visible in places like Harlem. At the time of finishing this intervention, August 2012, a small group of protestors continues to occupy the plaza during the day.

Day 3 : September 19.

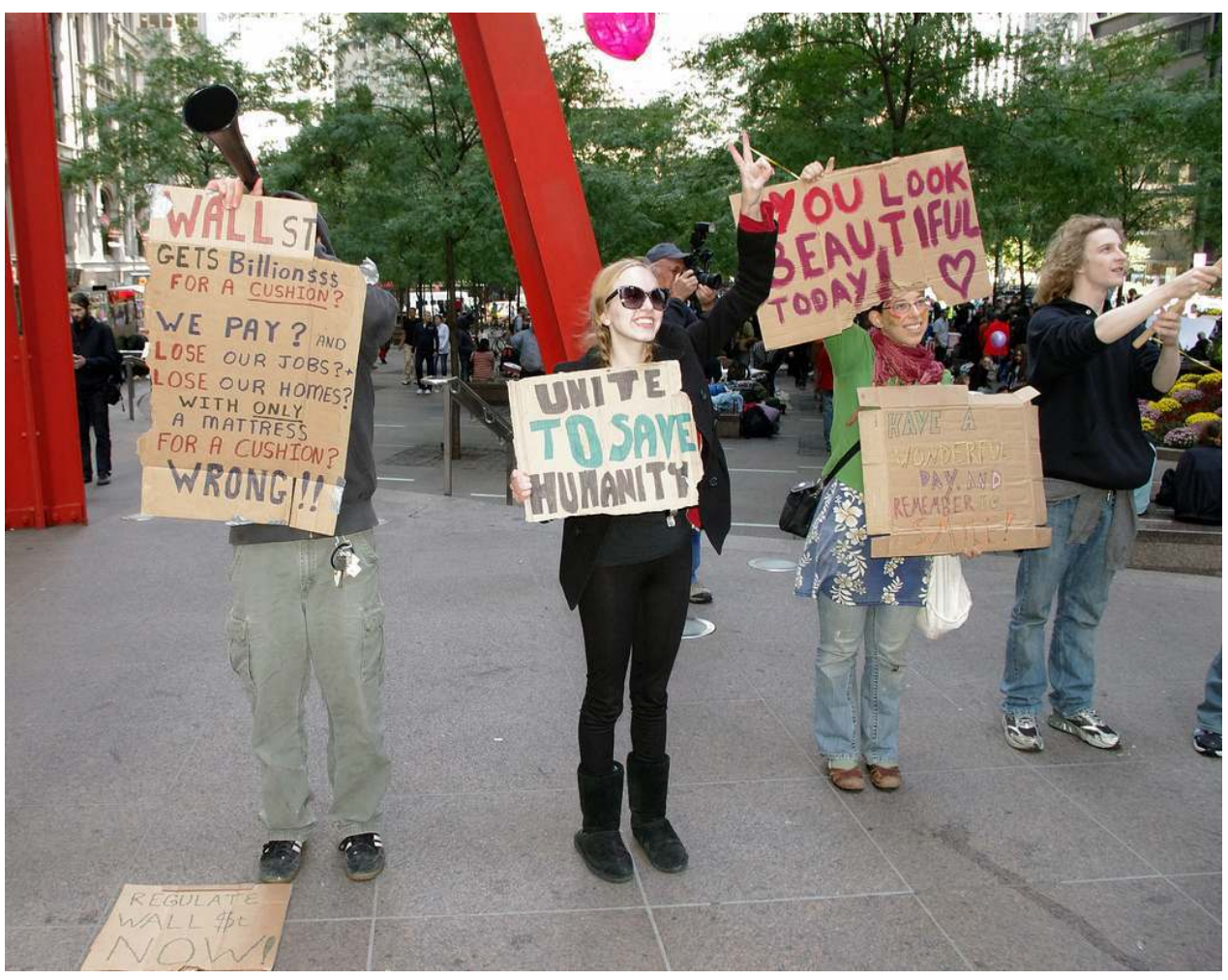

PHOTO: DAVID SHANKBONE, CREATIVE COMMONS.

\section{A Global Financial Political Geography}

5 The other problem Brookberg has with OWS is that it is hard to discuss with the protestors what should be done for them to leave Zuccotti Park. People who go on a hunger strike usually have very clear demands and so do participants in most other 
protests and occupations. Perhaps they want a $5 \%$ wage increase and will not leave an occupied place before they are promised to get those $5 \%$. They might then leave after a $3 \%$ wage increase has been offered. An employer might not be willing or able to offer a $5 \%$ wage increase but at least it is clear to the employer what should be done to end the strike. This is not the case at Occupy Wall Street. Will they leave once a Tobin tax has be introduced? Will they leave Zuccotti Park if all banks become nationalized ? Will they go home after lobbying by financial institutions is outlawed ? Will they party when the U.S. federal government will legally stop all home foreclosure procedures? What if CDOs and CDSs are declared illegal? And what if all investment banks and hedge funds become so tightly regulated that their market dries up and they either go bankrupt or are forced to change their business model ? We don't know and I suspect that most of the protesters do not know either.

The reason for this fundamental uncertainty is only in part a result of the heterogeneous nature of the occupiers. All social movements show a degree of heterogeneity but most still come up with a shared agenda. OWS so far hasn't because it fights against something that is much harder to identify: the contemporary, internationalized, financialized economy. One of the many things the current global financial and economic crisis demonstrates is that large parts of our economy are really beyond our control and often even beyond our imagination. No matter how many times we are explained how high frequency trading works, we might be able to explain it ourselves at some point, but do we really comprehend it? We used to think of the financial sector as a sector that made other things possible, a sector that enabled people to buy houses, students to go to college and entrepreneurs to start or expand their businesses. Many might have seen financial institutions as evil but most would agree that they were necessary evils. What the crisis revealed is that financial institutions engage in a great deal of activities that are not useful to the economy at all. A mortgage loan may enable someone to buy a home, but many predatory subprime loans were designed to disrupt rather than to disable homeownership. A credit default swap (CDS) may basically work like insurance, but most of them are simply bets against something. If a CDS were like fire insurance, most of them would not be taken out by homeowners but by others who plan to benefit from someone else's house burning down. The financial sector and media may call that innovation, but a lot of financial innovation is simply social destruction. 
Day 20: October 5, OWS prepares for the Foley Square march with community organizations and unions.

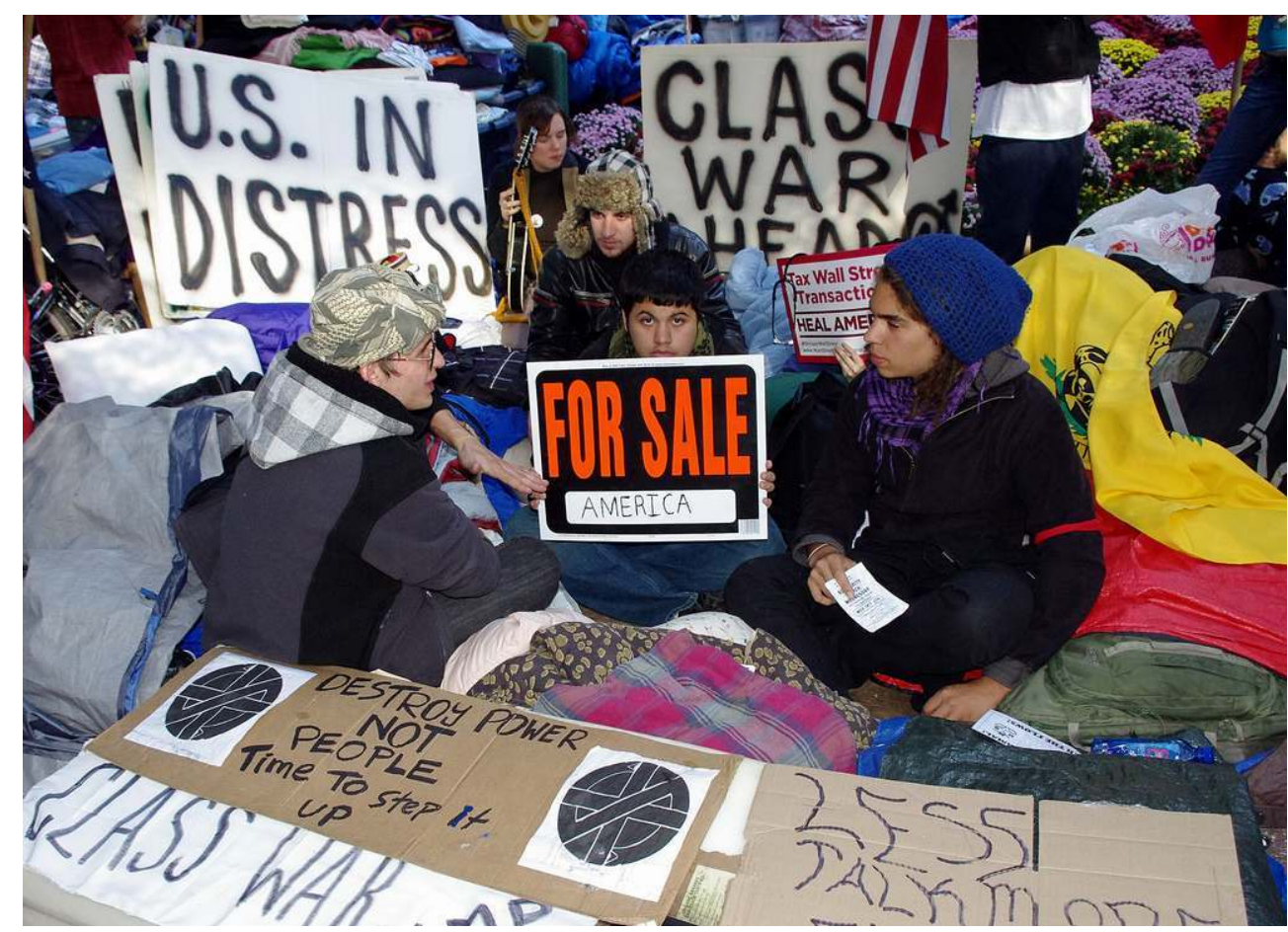

PHOTO: DAVID SHANKBONE, CREATIVE COMMONS.

7 There is a strong political dimension to all this. First, financial institutions heavily lobby states to get what they want, not just in the U.S. but also elsewhere. They did not only want less regulation, but sometimes more regulation to enable them to innovate/ destruct. This is not only something that happened in the decades prior to the financial crisis, but something that continues and has undermined re-regulatory efforts. Second, states, in particular though not exclusively in the U.S., have failed to protect their citizens. Financial institutions have been able to prey not only on homeowners and pensioners but also on businesses and the people who depend on them for their livelihoods. States are complicit to the crisis because they have facilitated financial innovation/destruction. They have stepped up but those steps have been too small to make up for the steps that they have gotten behind in the previous decades. Years of neoliberal restructuring, albeit in different forms and intensities, have not yet been repaired by a little more consumer protection and a little more financial regulation. The fundamental question of what state/market relations should be, has hardly been addressed. There is no simple answer and the answer is of course heavily politicized (as it should be), but the $99 \%$ are right that there is a general agreement about the underregulation and under-policing of financial institutions.

8 What OWS demands, is not simply the end of banking or the dismantling of investment banks; what it demands is a state that makes financial institutions serve their citizens rather than exploit them. Financial institutions, in particular banks, enjoy great privileges because of their role in the economy, but those state-sponsored privileges should be accompanied by a responsible state that promotes responsible banking rather than condoning innovation/destruction as a sign of free enterprise. In the $21^{\text {st }}$ century this is not merely the responsibility of individual states, it is increasingly the 
responsibility of states as a group. As long as there are tax havens, whether in microstates and crown dependencies or in generally well-respected countries such as Switzerland and the Netherlands, the responsibility of individual states is necessary but insufficient. A new Bretton Woods might be impossible and even undesirable, but that does not mean that states can ignore the necessity of stopping tax flight and the off-shoring of illegal financial practices. We need to discuss what responsible banking and statehood includes and how it should take shape, but we do already know what it should not include. The global unfolding of the occupy movement should be met by the global reshaping of state/ market relations.

\section{Day 43: October 29, the first day of snow.}

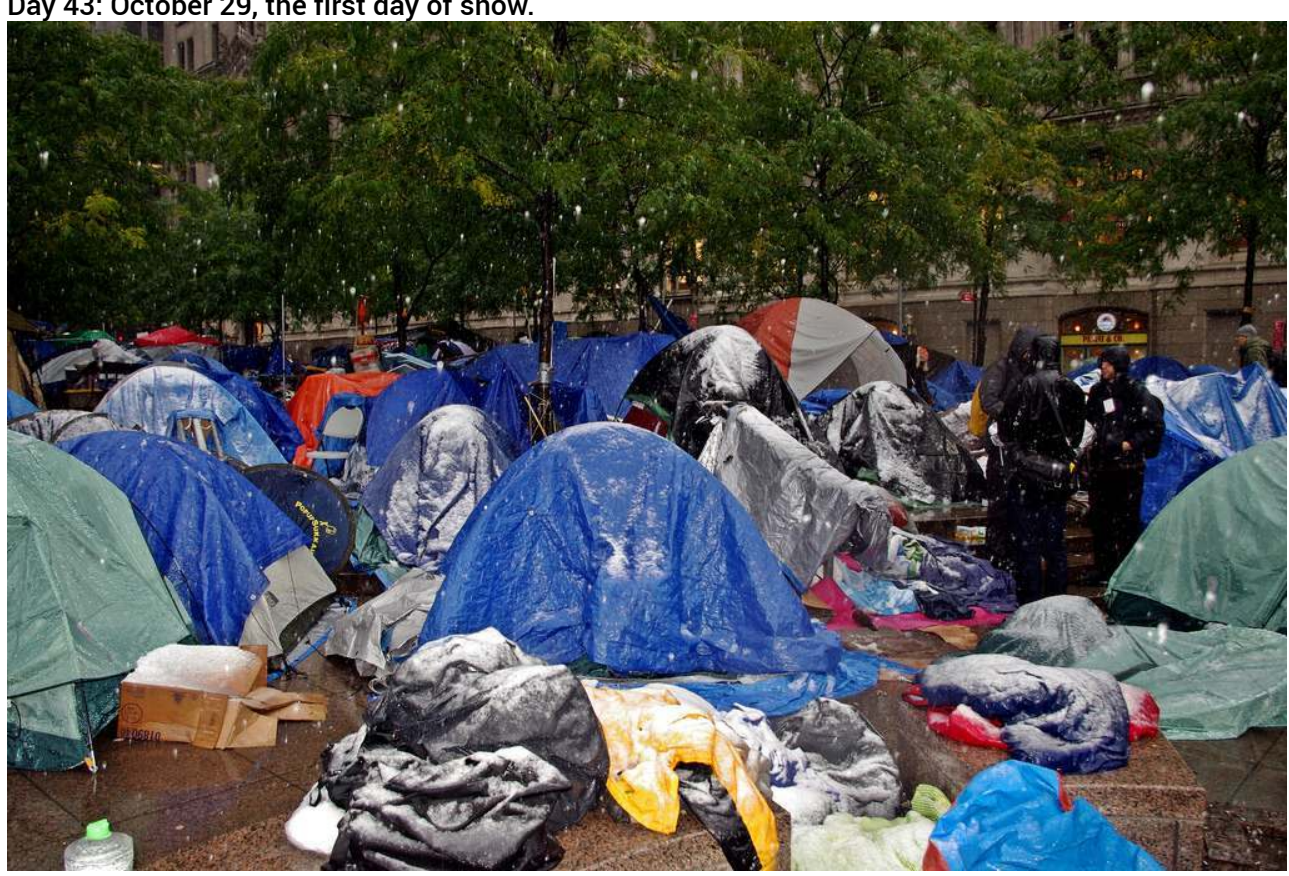

PHOTO: DAVID SHANKBONE, CREATIVE COMMONS.

\section{Conclusion}

Occupying Liberty Plaza as a place had a very symbolic function, not only because it is located in the enemy's territory, the Financial District, but also because it liberated the POPS known as Zuccotti Park and rechristened it as Liberty Plaza. Yet, the occupation of this particular place should not be fetishized : the goal of OWS is not to claim one small piece of publicly accessible privately-owned space but to question the financialized economy and to rethink state/market relations. During the occupation, the occupy movement has increasingly started cooperating with other community organizations and social movements such as Take Back the Land that liberate houses from the banks that occupy them, and those relations need to be expanded and mobilized. The occupation of the plaza has sparked parallel movements everywhere and it is now time to use the momentum to tackle the bigger issues at stake. There is an alternative; a different world is possible.

Acknowledgments

The author would like to thank Paulo Cunha for his suggestions 


\section{ABSTRACTS}

This short paper discusses two issues related to the Occupy Wall Street movement. First, a local urban political geography is presented in which Liberty Plaza is not the accidental place of Occupy Wall Street but a deliberate one, not only because it is located between the towers of global capital, but also because it constitutes a so-called "privately owned public space" (POPS). Second, a global financial political geography is presented in which I argue that the imprecise demands of Occupy Wall Street are a result not so much of the heterogeneous base of the movement but of the still largely unknown and "under-understood" nature of finance.

Ce court article est consacré à deux problèmes liés au mouvement "Occupy Wall Street". En premier lieu, nous présentons une géographie politique urbaine au niveau local dans laquelle le choix de la Plaza Liberty n'est pas accidentel mais bien délibéré, non seulement en raison de sa localisation entre les tours du capital global mais également parce que cette place représente un "espace public aux mains du privé". Dans un second temps, nous proposons une géographie politique de la finance globale, où nous défendons l'idée que les revendications assez floues du mouvement "Occupy Wall Street" résultent non pas tant du caractère hétérogène de sa base mais plutôt de la nature même de la finance, encore largement inconnue et "sous-comprise".

\section{INDEX}

Mots-clés: crise de la finance globale, espace public, financiarisation, zones, néolibéralisme, mouvement sociaux, Wall Street

Keywords: global financial crisis, public space, financialization, zoning, neoliberalism, social movements, Wall Street

\section{AUTHOR}

\section{MANUEL B. AALBERS}

Assistant professor at the Department of Geography, Planning and International Development Studies, University of Amsterdam and Visiting Scholar at Graduate Center, City University of New York. He is the editor of Subprime Cities: The Political Economy of Mortgage Markets (Wiley-Blackwell, 2012) and several papers on the financial crisis, M.B.Aalbers@uva.nl 